\title{
Communication revolutions: early iPads?
}

Since the 1440s the printing press has made the mass circulation of ideas possible. The Sibbald Library's first 2010 exhibition displayed some of the College's spectacular evidence of this communication revolution and invited viewers to muse on whether the evidence of our current digital revolution will be so usable in more than 500 years' time.

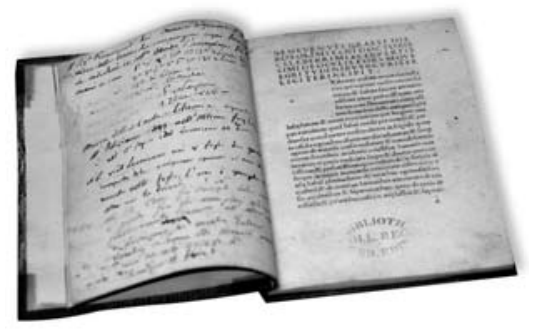

OUR EARLIEST PRINTED BOOK

De oculis eorumque aegritudinibus et curis

\section{Benvenuto Grassi}

(Severinus Ferrariensis, Ferrara, ?|474)

Benvenuto Grassi was the most celebrated ophthalmic surgeon of the Middle Ages. His dates are unknown, but he is thought to have been alive during the IIth and I2th centuries. Educated at Salerno, Grassi settled at Montpellier, where he was famous for cataract operations and ocular remedies. De oculis was the most popular ophthalmic manual of the Middle Ages and the first printed book on diseases of the eye. Regarded as the classic text for more than 500 years, it was reproduced in 22 manuscripts and 18 printed editions. The College copy has a manuscript herbal remedy for the eyes written on the end-paper.

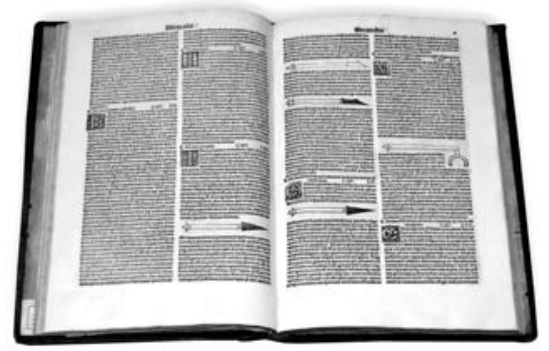

\section{THE BIRTH OF SURGERY}

Chirurgia parva and other works Guy de Chauliac (1300-68)

(Bonetus Locatellus for the heirs of Octavianus Scotus of Monza, Venice, I500/0I)
The Chirurgia parva was the standard surgical textbook for centuries.

Guy de Chauliac, born in what is now the Auvergne in France, was the most famous of the medieval surgeons. He was physician to Pope Clement VI during the Black Death and to his successors, Innocent VI and Urban V.

The Chirurgia parva is a condensed edition of the much more extensive Chirurgia magna. Some of the descriptions of surgical procedures are still applicable today. For example, de Chauliac advocated excising certain abnormal growths at an early stage. His works continued to be reprinted and translated until well into the 16th century. The RCPE edition includes more than 200 illustrations of surgical instruments. It also includes De oculis by the famous Arabian oculist Ali lbn Isa (known in medieval Europe as Jesu Occulist), which describes the anatomy, physiology and diseases of the eye.

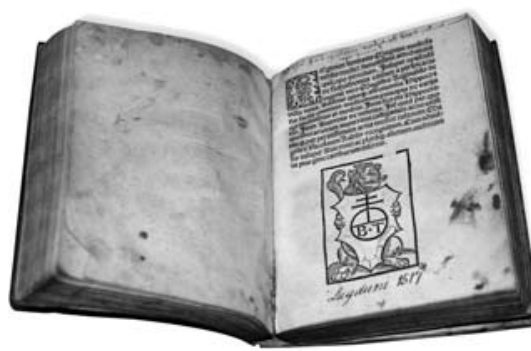

\section{EARLY MEDICAL SCHOOL LORE}

Regimen sanitatis magnini mediolanensis medici famosissimi attrebatensi episcopo directum (Jacobum Myt, Leyden, I517)

This popular work on diet and hygiene was a product of the medical school which flourished at Salerno from the IIth to the I4th century and is considered to be the first medieval medical school. The school produced books covering most aspects of medicine. The Regimen sanitatis was perhaps the most popular of all these texts. It contains rules on diet and hygiene and recommends simple drugs as a basis for treatment. By today's standards it is not a scientific book but more a collection of popular verse. It was popular for centuries and about 300 editions have been published.

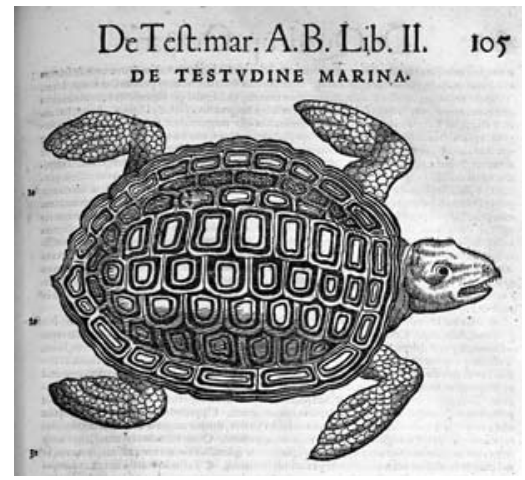

\section{RENAISSANCE ZOOLOGY}

Historiae animalium lib. I. de quadrupedibus uiuiparis Conradi Gesneri

(Christoph Froschauer, Zurich, I55I)

Konrad Gesner, one of the great polymaths of the 16th century, was professor of medicine and town physician at Zurich, where he died of the plague. His numerous writings covered a vast range of topics, and those on botany, zoology, medicine and pharmacology became standard reference works throughout Europe for more than 200 years. This work is regarded as the foremost zoological work of the Renaissance and the starting point of modern zoology. An encyclopedia of animal life, it contains illustrations and descriptions of all animals then known and consists of five large volumes containing some 3,500 pages and I,000 woodcut illustrations.

lain Milne Sibbald Librarian, RCPE 